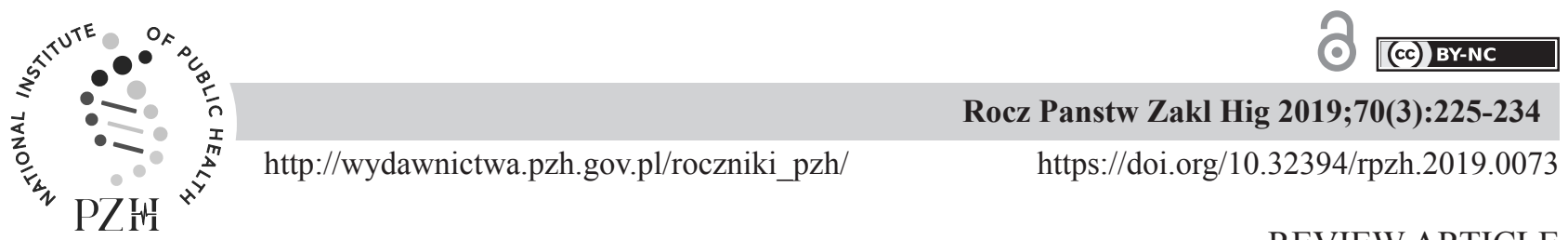

REVIEW ARTICLE

\title{
MOBILE TELEPHONY AND ITS EFFECTS ON HUMAN HEALTH*
}

\author{
Andrzej Magiera ${ }^{1}$, Jolanta Solecka ${ }^{1}$ \\ ${ }^{1}$ National Institute of Public Health - National Institute of Hygiene, \\ Department of Environmental Health and Safety, 24 Chocimska str., 00-791 Warsaw, Poland
}

\begin{abstract}
In recent years, there has been a rapid increase in the number of electromagnetic radiation sources such as mobile phones and base stations of mobile telephony. This radiation has been classified by the International Agency for Research on Cancer as a possible human carcinogen (group 2B). For this reason, many studies have been carried out on the impact of mobile telephony on human health. The largest of the experiments were carried out on animals. Due to the divergent results of many studies, there was no clear answer on the possible carcinogenic effects of this type of radiation on health. Detection of cancer shortly after an exposure is the most difficult task in analyzing the results. Some of the studies require repetition and verification of the results. In the case of negative effects of electromagnetic fields on brain activity, sleep, heart rate, cognitive function and blood pressure, no consistent evidence has been obtained either. In view of the increasing popularity of mobile phones, their location at short distances from the body (mainly the head) and the development of mobile phone technologies (which entails an increase in the number of base stations), further research, especially among young people, is needed. The duration of human exposure to electromagnetic radiation is subject to an increase and only further research can provide an answer on the possible negative effects of mobile phones and base stations.
\end{abstract}

Key words: electromagnetic wave, radiofrequency radiation (RFR), mobile phone, base station, health aspects

\section{STRESZCZENIE}

W ostatnich latach nastąpił gwałtowny wzrost liczby źródeł promieniowania elektromagnetycznego jakimi są telefony komórkowe i stacje bazowe telefonii komórkowej. Promieniowanie to zostało sklasyfikowane przez Międzynarodową Agencję Badań nad Rakiem jako czynnik przypuszczalnie rakotwórczy dla człowieka (grupa 2B). Z tego powodu dokonano wielu badań dotyczących wpływu telefonii komórkowej na zdrowie ludzi. Największe z eksperymentów zostały przeprowadzone na zwierzętach. Ze względu na rozbieżne wyniki wielu badań nie otrzymano jednoznacznej odpowiedzi na temat ewentualnego rakotwórczego wpływu tego rodzaju promieniowania na zdrowie. Wykrywanie nowotworów po krótkim czasie od narażenia jest największą trudnością w analizie otrzymanych wyników. Część z badań wymaga powtórzenia i weryfikacji wyników. W przypadku negatywnego wpływu pola elektromagnetycznego na aktywność mózgu, sen, tętno, funkcje poznawcze oraz ciśnienie krwi również nie otrzymano żadnych spójnych dowodów. W związku z coraz większą popularnością telefonów komórkowych, usytuowaniem ich w niewielkich odległościach od ciała (głównie głowy) oraz rozwojem technologii związanych z telefonią komórkową (która pociąga za sobą wzrost liczby stacji bazowych) niezbędne są dalsze badania przeprowadzane w szczególności wśród młodych ludzi. Okres narażenia człowieka na promieniowanie elektromagnetyczne wydłuża się i tylko dalsze badania mogą dać odpowiedź na temat ewentualnego negatywnego wpływu telefonów komórkowych i stacji bazowych.

Słowa kluczowe: fala elektromagentyczna, promieniowanie elektromagentyczne częstotliwości radiowych, telefon komórkowy, stacja bazowa telefonii komórkowej, aspekty zdrowotne

\section{ELECTROMAGNETIC WAVES}

Radiation is a way of energy transfer through the emission of particles or electromagnetic waves without requiring a material medium between the emission source and the receiver. Electromagnetic waves can propagate in a vacuum. An electromagnetic wave is created by a moving electric charge that generates

Corresponding author: Andrzej Magiera, National Institute of Public Health - National Institute of Hygiene, Department of Environmental Health and Safety, 24 Chocimska str., 00-791 Warsaw, Poland, tel. +48 225421 423, e-mail: amagiera@pzh.gov.pl

*This article in the Polish language version is published on the journal's website.

(C) Copyright by the National Institute of Public Health - National Institute of Hygiene 
a flow of electric current. A magnetic field appears in the vicinity of an electric current. When the current is alternating, the magnetic field is also alternating. An alternating magnetic field induces an alternating electric field (Faraday's law) and an alternating electric field induces an alternating magnetic field (Ampère's circuital law with Maxwell addiction). If one field vibrates, the other field also vibrates (in a plane perpendicular to itself). These vibrating fields reproduce each other and contribute to the formation of an electromagnetic wave. A field strength (electric and magnetic) decrease rapidly as the distance increases. Pursuant to Article 3 (18) of the Act of 27 April 2001, Environmental Protection Law (Journal of Laws of 2018, item 799), an electromagnetic field is an electric, magnetic and electromagnetic field with frequencies from $0 \mathrm{~Hz}$ to $300 \mathrm{GHz}$ [16]. Electric, magnetic and electromagnetic fields are intrinsic to the environment and naturally occur within it.

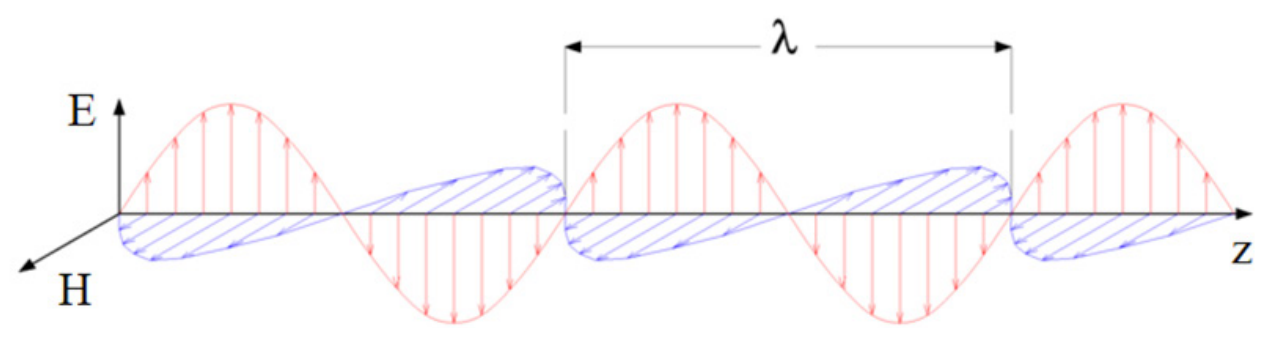

Figure 1. Electromagnetic wave (electric and magnetic field strength)

The electromagnetic wave is described by the following values:

- E $\left[\frac{V}{m}\right]$ - electric field strength,

- $\mathrm{H}\left[\frac{A}{m}\right]-$ magnetic field strength,

- $\mathrm{v}\left[\frac{m}{s}\right]$ - electromagnetic wave propagation velocity,

- $v[\mathrm{~Hz}]$ - frequency - the number of complete magnetic and electric field changes per second,

- $\mathrm{T}[s]$ - period of variability - reversal of frequency, i.e., time when the return to the same phase of electric and magnetic field will take place,

- $\lambda[m]$ - wavelength - distance between adjacent points where electric and magnetic fields have the same phase.

Electromagnetic radiation can be treated both as an electromagnetic wave (propagation in space of changing electric and magnetic fields) and as a stream of small portions of energy - photons (wave- particle duality). The figure 2 shows the spectrum of electromagnetic radiation with marked frequency and wavelength.

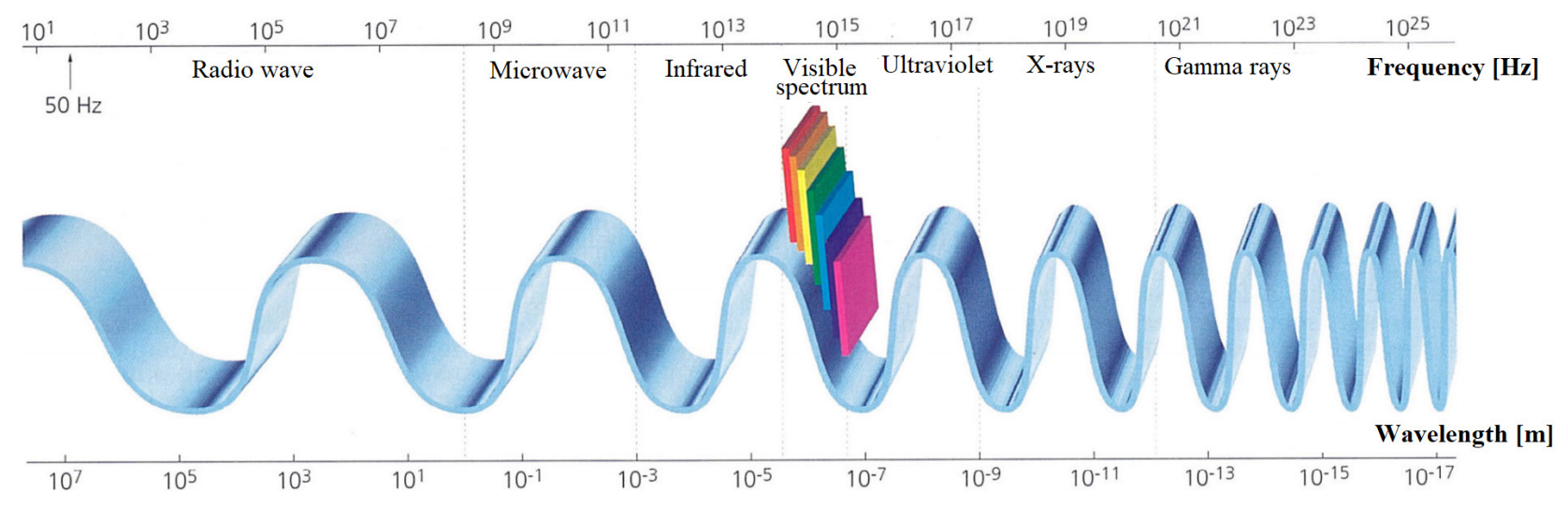

Figure 2. The spectrum of electromagnetic radiation [11]

\section{ELECTROMAGNETIC FIELD SOURCES - MOBILE TELEPHONY}

The development of civilization has caused a huge number of sources of electromagnetic fields. These sources are, inter alia, mobile phones and radio-communication installations, including mobile telephony, the so-called base stations. In recent years, this field of telecommunications has developed very dynamically, which caused a rapid increase in the number of mobile phones users. As a result, the problem of exposure to radiation from mobile 
phones and base stations has become the subject of research and analysis as it now affects the majority of the population. The risk concerns not only people using mobile phones, but also people in the area of base station radiation. The problem is exacerbated in densely populated areas, mainly in large cities where the number of mobile phone users and base stations is the highest.

A mobile phone is an electronic device that allows the user to have radio contact with the telephone network and to transmit information (making a call, sending text messages, using the Internet). This device converts voice into an electric signal, which in turn is transmitted on radio frequencies. The other phone receives this signal and converts it into voice. The antenna in mobile phones is placed inside the phone. The power radiated by mobile phones depends on the conditions between the phone and the base station (distance, obstacles). If the conditions between the phone and the base station deteriorate (the distance between the phone and the base station increases or there are any mechanical obstacles in the radio channel), then the device increases its power, trying to maintain a satisfactory quality of connection. The mobile phone works with its maximum output power at the beginning of the call. The power drops when an appropriate level is recognized to maintain a smooth connection.

Mobile phones communicate only with the base stations, never directly with each other. This contact is possible in places within the range of the base stations of mobile telephony, i.e., places where the electromagnetic radiation emitted by them reaches. The distance between the transmitter and receiver is called the radio channel. The level of electromagnetic radiation emitted by the base station of mobile telephony depends on the distance from the station to the place of reception and the type of obstacles between them: noise, interference, Doppler effect, etc. The area served by the base station (within its range) is a cell, thus the name "cellular telephone" originates from this area. The range of the cells depends on the population of the area. The maximum radius of the range is several kilometers (sparsely populated areas). For densely populated areas (e.g. large cities) the range can reach even several dozen meters (so-called picocells).

Two areas can be distinguished in the field of electromagnetic radiation sources (mobile phone or mobile telephony base station), depending on the distance from the source: near field and far field. It is assumed that the near field has its boundary at a distance of $\frac{2 D^{2}}{\lambda}$, where $\mathrm{D}$ is the maximum size of the antenna and $\lambda$ is the wavelength of electromagnetic radiation. When using a mobile phone, one may limit oneself to considering only the near field, in case of the base station impact on human and environmental - the far field.

There are three zones around the base station: good audibility zone, interference zone for other systems operating at the same frequencies, and negligible zone. Mobile networks are designed in such a way that two transmitters (base stations) of the same frequency operate at the lowest possible interference. This is done in such a way that the area of the interference zone does not overlap the area of the good audibility zone of another base station. There is a finite number of frequencies on which the signal is transmitted and received (for each call two frequencies assigned to the call are needed). The two available frequencies may be repeated in independent network cells. There is a limit for neighboring cells. Each call is made at a different frequency. If all possible frequencies are occupied (a large number of mobile phone users make calls at the same time), the network may be overloaded.

The number of base stations depends, inter alia, on the number of people in a given area - the higher the population density, the higher the number of base stations. Due to the location of base station antennas high up on the roofs of buildings, chimneys and masts, a good quality of connection is ensured.

Mobile networks use frequencies in the 900, 1800 (second generation GSM) and $2100 \mathrm{MHz}$ (third generation $3 \mathrm{G}$ ) bands to connect with subscribers. The number of mobile base stations is linked to the number of subscribers to such systems. According to data provided by Statistics Poland, the number of mobile network subscribers in Poland has been growing rapidly over the last twenty years (in recent years, this number has not been growing so fast). The data are presented in the figure 3. The relationship between the number of mobile network subscribers in Poland and the number of base stations is presented in the figure 4 . It can be noted that one base station served on average around 2000 mobile users at the beginning of the mobile telephony development. Over the years, the ratio of the number of mobile subscribers to the number of base stations has been decreasing. This is due to the steadily increasing number of base stations. Subsequent generations of mobile networks mean increasing frequency to connect with subscribers. The lower the frequency, the greater the area covered by the radio waves. The higher the frequency, the better signal quality (allows faster data transmission), but at the same time less range and more problems with physical obstacles overcoming. This means that it is necessary to build quite complicated and densely located infrastructure (base stations). The more stations, the less radiation is emitted by a mobile phone.

According to the data collected by the International Telecommunication Union / Worldbank (https://data. 
worldbank.org), the number of mobile phone users in Poland (as of 2017) is approximately 49.8 million [10], which is similar to the data available at Statistics Poland. The population in Poland (as of 2017) amounts to about 38.0 million [15]. It can be noted that there are 1.31 mobile phones per capita in Poland. For comparison, this ratio is similar worldwide. The number of mobile phone users (as of 2017) amounts to about 7.7 billion. The world population (as of 2017) amounts to 7.53 billion (the ratio is 1.02) [7].

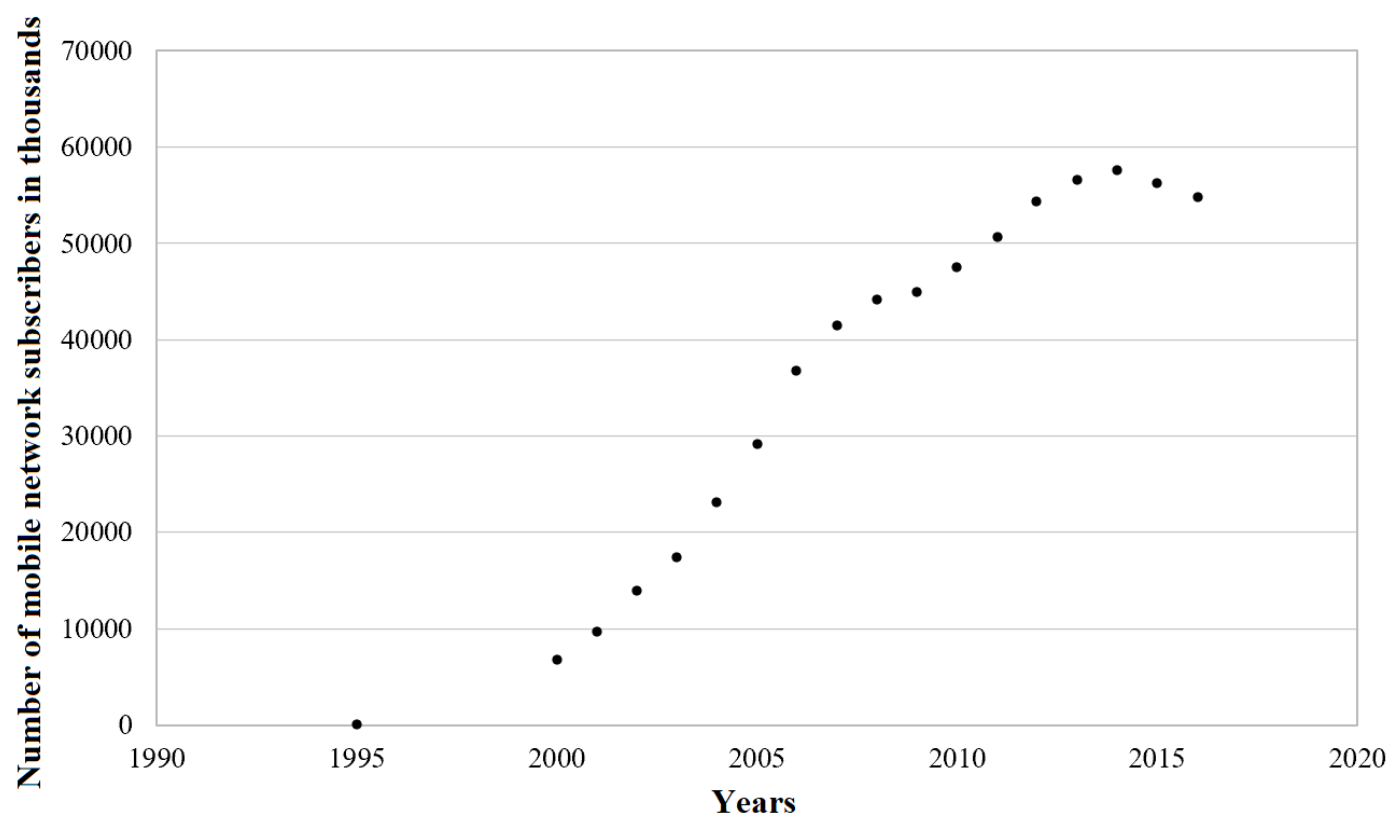

Figure 3. Number of mobile network subscribers in thousands in the years 1995-2016 [15]

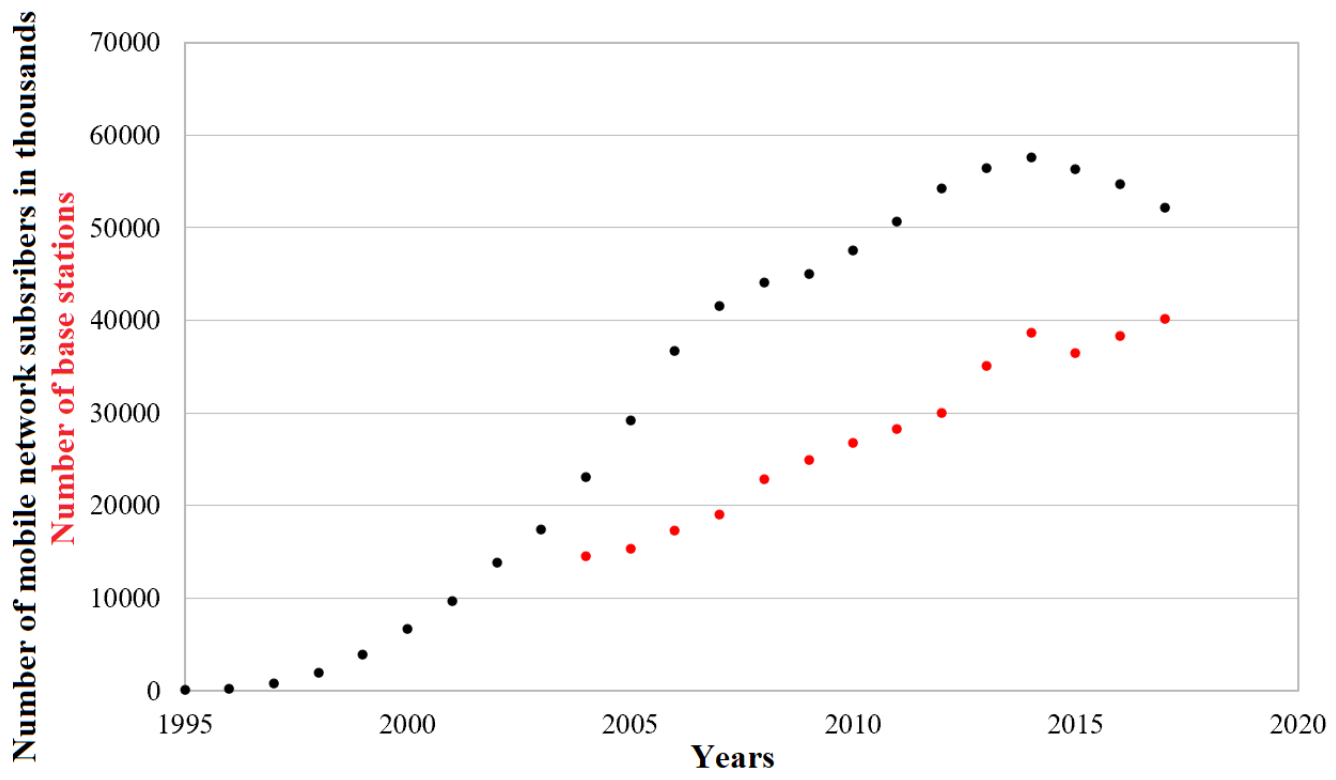

Figure 4. Number of mobile subscribers in thousands (1995-2017) and number of base stations in Poland (2004-2017) [15]

\section{LEGAL REGULATIONS}

Due to the presence of a huge number of sources geerating electromagnetic fields (including mobile phones and base stations) in the natural environment, legal regulations on environmental protection against electromagnetic fields have been developed in Poland and worldwide. The basic legal act in Poland is the Act of 27 April 2000 - Environmental Protection Law
(Journal of Laws of 2018, item 799). Article 121 of the aforementioned Act states that protection against electromagnetic fields consists in ensuring the best possible condition of the environment through:

1. maintaining electromagnetic field levels below or at least at the permissible levels;

2. reducing the levels of electromagnetic fields to at least acceptable levels where these are not observed [16]. 
Pursuant to Article 122 of the aforementioned Act, acceptable levels of electromagnetic fields in the environment have been determined for areas intended for housing development and for areas accessible to the public (Regulation of the Minister of the Environment of 30 October 2003 on permissible levels of electromagnetic fields in the environment and methods of verifying compliance with these levels (Journal of Laws of 2003, No. 192, item 1883)). The tables 1 and 2 present the permissible levels of electric and magnetic field strength depending on the frequency.

Table 1. Reference levels for electric and magnetic field strength and power density depending on the frequency for areas designed for housing development [14].

\begin{tabular}{|c|c|c|c|c|}
\hline \multicolumn{2}{|c|}{$\begin{array}{l}\text { Frequency } \\
\text { range }\end{array}$} & \multicolumn{3}{|c|}{ Physical quantity } \\
\cline { 2 - 5 } & $\begin{array}{c}\text { Electric } \\
\text { field } \\
\text { strength } \\
{[\mathrm{kV} / \mathrm{m}]}\end{array}$ & $\begin{array}{c}\text { Magnetic } \\
\text { field } \\
\text { strength } \\
{[\mathrm{A} / \mathrm{m}]}\end{array}$ & $\begin{array}{c}\text { Equivalent plane } \\
\text { wave power } \\
\text { density } \\
{\left[\mathrm{W} / \mathrm{m}^{2}\right]}\end{array}$ \\
\hline 1 & 1 & 2 & 3 & 4 \\
\hline 1 & $50 \mathrm{~Hz}$ & 1 & 60 & - \\
\hline
\end{tabular}

Table 2. Reference levels for electric and magnetic field strength and power density depending on the frequency for areas accessible to the public [14].

\begin{tabular}{|c|c|c|c|c|}
\hline \multirow{2}{*}{\multicolumn{2}{|c|}{}} & \multicolumn{3}{|c|}{ Physical quantity } \\
\cline { 2 - 5 } Frequency range & $\begin{array}{c}\text { Electric } \\
\text { field } \\
\text { strength } \\
{[\mathrm{V} / \mathrm{m}]}\end{array}$ & $\begin{array}{c}\text { Magnetic } \\
\text { field } \\
\text { strength } \\
{[\mathrm{A} / \mathrm{m}]}\end{array}$ & $\begin{array}{c}\text { Equivalent } \\
\text { plane } \\
\text { wave } \\
\text { power } \\
\text { density } \\
{\left[\mathrm{W} / \mathrm{m}^{2}\right]}\end{array}$ \\
\hline 1 & 1 & 2 & 3 & 4 \\
\hline 2 & $0-0,5 \mathrm{~Hz}$ & - & 2500 & - \\
\hline 3 & $0.5-50 \mathrm{~Hz}$ & 10000 & 60 & - \\
\hline 4 & $0.05-1 \mathrm{kHz}$ & - & $3 / \mathrm{f}$ & - \\
\hline 5 & $0.001-3 \mathrm{MHz}$ & 20 & 3 & - \\
\hline 6 & $3-300 \mathrm{MHz}$ & 7 & - & - \\
\hline 7 & $0.3-300 \mathrm{GHz}$ & 7 & - & 0.1 \\
\hline
\end{tabular}

For frequencies reserved for current mobile telephony, the permitted level of the electric field strength is $7 \mathrm{~V} / \mathrm{m}$. For the magnetic field strength, this value is not specified.

In the European Union there is another legal act in force concerning the protection of the public against electromagnetic fields - Council Recommendation of 12 July 1999 on the limitation of exposure of the general public to electromagnetic fields $(0 \mathrm{~Hz}$ to 300 $\mathrm{GHz}$ ). It also presents the limit values for electric and magnetic field strength of the electromagnetic field (Table 3).
Table 3. Reference levels for electric and magnetic field strength and power density depending on the frequency [3]

\begin{tabular}{|c|c|c|c|c|}
\hline \multicolumn{2}{|c|}{} & \multicolumn{3}{|c|}{ Physical quantity } \\
\cline { 3 - 5 } Frequency range & $\begin{array}{c}\text { Electric } \\
\text { field } \\
\text { strength } \\
{[\mathrm{V} / \mathrm{m}]}\end{array}$ & $\begin{array}{c}\text { Magnetic } \\
\text { field } \\
\text { strength } \\
{[\mathrm{A} / \mathrm{m}]}\end{array}$ & $\begin{array}{c}\text { Equivalent } \\
\text { plane wave } \\
\text { power } \\
\text { density } \\
{\left[\mathrm{W} / \mathrm{m}^{2}\right]}\end{array}$ \\
\hline 1 & 1 & 2 & 3 & 4 \\
\hline 2 & $1-8 \mathrm{~Hz}$ & 10000 & $3.2 \cdot 10^{4} / \mathrm{f}^{2}$ & - \\
\hline 3 & $8-25 \mathrm{~Hz}$ & 10000 & $4000 / \mathrm{f}$ & - \\
\hline 4 & $0.025-0.8 \mathrm{kHz}$ & $250 / \mathrm{f}$ & $4 / \mathrm{f}$ & - \\
\hline 5 & $0.8-3 \mathrm{kHz}$ & $250 / \mathrm{f}$ & 5 & - \\
\hline 6 & $3-150 \mathrm{kHz}$ & 87 & 5 & - \\
\hline 7 & $0.15-1 \mathrm{MHz}$ & 87 & $0.73 / \mathrm{f}$ & - \\
\hline 8 & $1-10 \mathrm{MHz}$ & $87 / \mathrm{f}^{1 / 2}$ & $0.73 / \mathrm{f}$ & - \\
\hline 9 & $10-400 \mathrm{MHz}$ & 28 & 0.073 & 2 \\
\hline 10 & $400-2000 \mathrm{MHz}$ & $1.375 \mathrm{f}^{1 / 2}$ & $0.0037 \mathrm{f}^{1 / 2}$ & $\mathrm{f} / 200$ \\
\hline 11 & $2-300 \mathrm{GHz}$ & 61 & 0.16 & 10 \\
\hline
\end{tabular}

In the frequency range from 1 to $25 \mathrm{~Hz}$, reference levels for electromagnetic fields (electric field strength) are the same for the Polish legal regulations and the recommendations of the European Union. Over 25 $\mathrm{Hz}, \mathrm{EU}$ regulations are more restrictive than national regulations. The exception is the frequency of $50 \mathrm{~Hz}$ (frequency of electricity transmission), for which the limit value included in the regulation of the Minister of the Environment for areas designated for housing development is $1000 \mathrm{~V} / \mathrm{m}(5000 \mathrm{~V} / \mathrm{m}$ according to the recommendation of the European Union). For higher frequencies (from $1 \mathrm{kHz}$ to $300 \mathrm{GHz}$, i.e., also for radio frequencies used in mobile telephony) the permissible levels of electromagnetic fields are much lower in Poland than in the majority of European countries. Polish legal regulations related to protection against electromagnetic fields are among the most restrictive in Europe.

Article 122a of the Environmental Protection Law Act states that the installer and user of device emitting electromagnetic fields, which are electromagnetic stations or overhead electromagnetic lines with a rated voltage not lower than $110 \mathrm{kV}$, or radio-communication, radio-navigation or radiolocation installations, emitting electromagnetic fields, with an isotropically equivalent radiated power of not less than $15 \mathrm{~W}$, emitting electromagnetic fields with frequencies from $30 \mathrm{kHz}$ to $300 \mathrm{GHz}$, are obliged to perform measurements of the levels of electromagnetic fields in the environment:

1. immediately after the installation or device has been put into service;

2. whenever there is a change in the operating conditions of the installation or device, including changes caused by changes in installation or device equipment, so far as such changes are likely to affect the level of electromagnetic fields originating from the installation or device [16]. 
Pursuant to Article 123 of the Environmental Protection Law Act, the levels of electromagnetic fields in the environment are assessed within the framework of the National Monitoring of the Environment and the levels of these fields are examined by the Provincial Inspectorates for Environmental Protection. The figure 5 presents data from recent years concerning the average levels of the electric field strength for Poland.

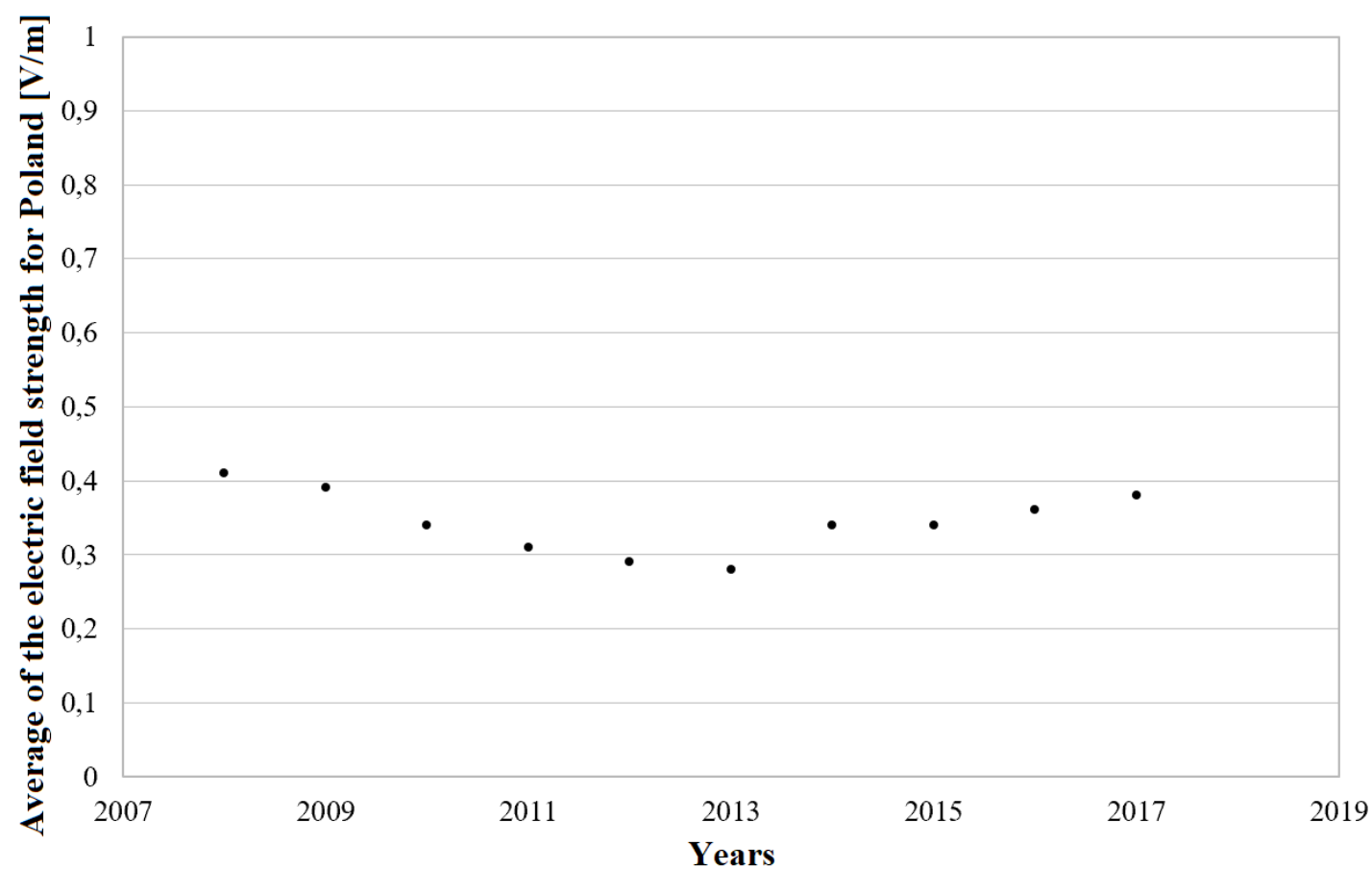

Figure 5. Average of the electric field strength for Poland in the years 2008-2017 [1].

It can be noted that despite the continuous increase in the number of base stations in Poland, the level of electromagnetic radiation of high frequencies (here expressed as an electric field strength) is maintained at a constant level. These values constitute about $5 \%$ of the value of the permissible electrical component for these frequency ranges. These values are the highest for large cities (over 50,000 inhabitants). In 2017, the value of the average level for central districts or city settlements above 50,000 in the Mazowieckie Voivodeship was $0.89 \mathrm{~V} / \mathrm{m}$ (which constitutes about $13 \%$ of the permissible value). The highest value was recorded in Warsaw at the crossroads of Al. Jerozolimskie and Marszałkowska streets. This value was $2.38 \mathrm{~V} / \mathrm{m}$ ( $34 \%$ of the limit value) [1].

In connection with the continuous development of technology related to mobile telephony, including the implementation of the fifth generation $(5 \mathrm{G})$ network in Poland, it is necessary to continue monitoring of the value of electromagnetic field levels from telecommunications installations. Therefore, the Ministry of Digital Affairs has prepared a document - 5G Strategy for Poland, which defines actions and measures for the implementation of the fifth generation network in Poland. In 2019, with the participation of the National Institute of Telecommunications - the State
Research Institute, it is planned to commence work on permanent monitoring and research of electromagnetic fields in the radio range. The aforementioned national research and development institution is also responsible for building and making available an information system on installations generating electromagnetic radiation, ensuring completeness and consistency of data related to these installations and facilitating an access for citizens and administration to relevant environmental data concerning electromagnetic fields [18].

\section{HEALTH EFFECTS OF MOBILE PHONES AND BASE STATIONS}

Electromagnetic radiation from the radio frequency range passing through a specific material medium loses part of its energy by passing it to the medium. Depending on the type of tissue, the absorption of radiation varies. Tissues with high water content (e.g. muscle tissue) quickly absorb radiation (heat up), unlike tissues with low water content (e.g. adipose tissue). The electromagnetic wave is attenuated by penetrating into human tissues. The rate of attenuation is an exponential function and depends on the frequency of the wave. When a wave passes 
through a given material medium, e.g. human tissues, the wave changes its wavelength and velocity. Apart from sight, which detects visible light or skin detecting infrared radiation, i.e., heat, living organisms do not have appropriate receptors to detect the presence of electromagnetic field. This radiation passes through the body unnoticeably.

Electromagnetic fields in frequencies from $1 \mathrm{MHz}$ to $10 \mathrm{GHz}$ penetrate into human tissues and deposit some of their energy in the form of heat. The depth of tissue penetration depends on the frequency: the lower the frequency, the deeper the penetration. Harmful biological effects depend on the amount of absorbed energy [6]. Knowing the frequency of the wave and the type of tissue through which the wave passes, it is possible to determine the depth of penetration of the wave and thus the maximum range of thermal effects in the tissue. To quantify the dose of absorbed radiation, the Cellular Telecommunications Industry Association (CTIA) has introduced the Specific Absorption Rate (SAR), which is the amount of electromagnetic wave energy in the radio range expressed in watts absorbed by a kilogram of body weight (SAR unit is $\mathrm{W} / \mathrm{kg}$ ). For SAR values above $4 \mathrm{~W} / \mathrm{kg}$, harmful effects are observed in the human body. Electromagnetic fields with frequencies above $10 \mathrm{GHz}$ are mostly absorbed by human skin and only a small part of the energy can reach deeper layers of the body, including internal organs [6].

Human tissues are mainly made up of water, which contains many different types of ions. Under the influence of an electromagnetic field, particles and ions are exposed to electrical forces that can cause the flow of dissolved ion currents. As a result, the temperature in the tissues increases. When the flow of ions is not possible, the electric field causes oscillations and rotations of molecules encountering resistance of intermolecular forces. This also results in heat. Each biological system absorbs the radiation energy and thus increases its temperature (the so-called thermal effect).

Electromagnetic radiation is classified as nonionizing radiation. The energy range of electromagnetic radiation, which is several orders of magnitude below the energy of chemical bonds in molecules, is insufficient to cause ionization of atoms or molecules or to break the chemical bonds. Therefore, the probability of inducing modification of molecular structures, excitation of biomolecules or DNA damage is negligible.

An effect of electromagnetic radiation on human tissues mainly depends on the duration of exposure. For short exposure time (less than $0.5 \mathrm{~min}$.) the transport of heat in the tissues can be neglected. In the case of exposure lasting several minutes, the thermal effect and temperature distribution cannot be ignored. The strongest effects associated with electromagnetic radiation absorption are observed in the surface layers (close to the skin surface). The most sensitive are the organs with poor blood supply and localized shallowest - eyes and testicles.

Care should be taken when estimating the risk associated with an exposure to electromagnetic fields. In recent years, there has been a large increase in the incidence of e.g. thyroid cancer. This increase is caused by the increasing availability of diagnostic procedures related to ionizing radiation $-\mathrm{X}$-ray radiation (dental radiology, computed tomography, etc.). At the same time, the development of mobile telephony has taken place, which entails an increase in exposure to electromagnetic radiation from the radio range. It can be noted that at the same time various environmental factors appeared, which simultaneously affect humans and the environment [2].
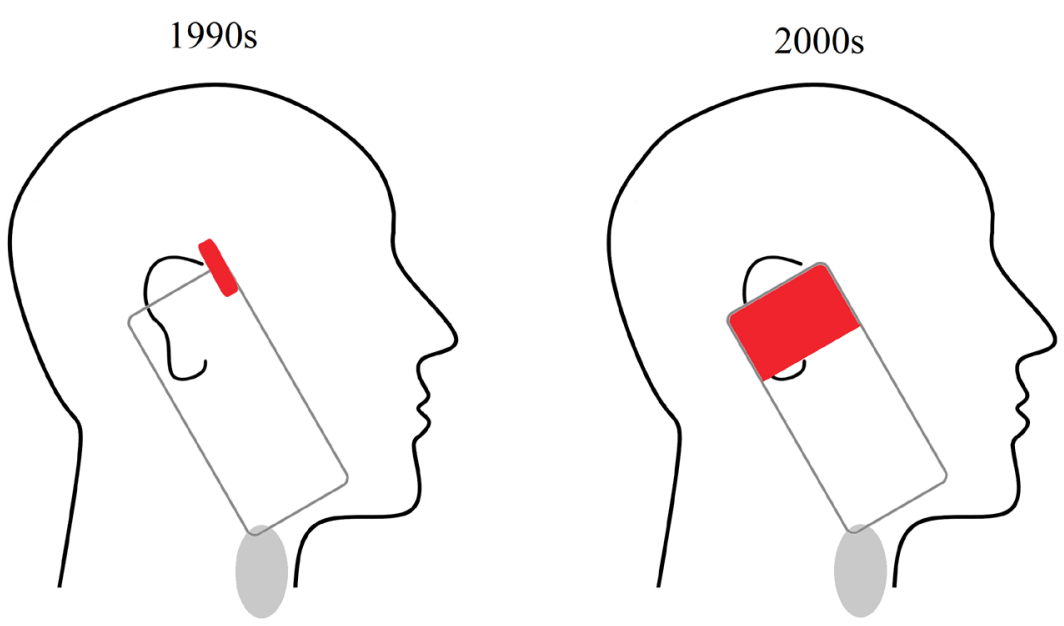

Figure 6. Location of antennas installed in cellular phones from the 1990s to the present day [2]. 
In recent years, the location of antennas installed in mobile phones has changed slightly (figure 6). The current models have antennas occupying about 1/4 of the mobile phone volume and are located in the lower part of the phone. Thus, the distance from the radiation-sensitive organ which is the thyroid gland has decreased.

Mobile phones work with an average power of about $2 \mathrm{~W}$. This is much less than the power of a base station, which can be several kilowatts. Despite the fact that mobile phones work with much less power than the base stations, they have a much larger share in the amount of electromagnetic energy transmitted to humans. During a telephone conversation, the phone is located right next to the user's head. The head is very sensitive to electromagnetic radiation, which can cause danger to the human body despite the low signal strength. The intensity of electromagnetic field decreases with the distance, so mobile phones affect the human body more than the base stations (short distances from the body, right next to the head). When a mobile phone user uses a headset during a conversation, the amount of energy absorbed by the head can be significantly reduced.

\section{RECENT STUDIES AND EXPERIMENTS ON THE IMPACT OF MOBILE PHONES AND BASE STATIONS ON ANIMALS AND HUMANS}

Existing studies on the impact of mobile phones and base stations are not considered very accurate. The ambiguity of the results of the research and experiments carried out may be due to the way in which electromagnetic fields are simulated. There is a large difference in the actual emissions of telephones and base stations compared to the generators and test telephones used for the studies. The radiation emitted during a real connection is characterised by a high variability in time and is therefore much more dangerous for living organisms that are less resistant to environmental factors varying in time. Despite strong criticism of the studies (by, inter alia, the International Agency for Research on Cancer) in which real conditions are used (telephones that change the frequency and intensity of radiation during work), increasing number of experiments have been conducted in such conditions in recent years. There is a belief that only research conducted in real working conditions of mobile phones can give a clear answer and information about human exposure to (nonionizing) electromagnetic radiation [13].

Most of the epidemiological studies related to an exposure to electromagnetic radiation are questionnaire surveys. Unfortunately, these studies are very inaccurate and burdened with a lot of uncertainty.
This is related to public unawareness about the impact of electromagnetic fields on health and exposure size. The level of exposure perceived by the public differs significantly from the actual exposure from the source. It appears that the exposure from base stations is much lower than that from mobile phones. The opposite opinions were noted in the studies concerning human knowledge on the subject. Respondents considered that base stations had a greater impact than mobile phones [5].

The National Toxicology Program (NTP), an interagency program within the U.S. Department of Health and Human Services presented two technical reports announced in early 2018. They published the first results of many years of experiments on the effects of electromagnetic fields on near field and the associated small increase in the incidence of malignant gliomas (tumor of the brain) and schwannomas (tumor of the heart) in rats and mice. In the first experiment, animals (rats) were exposed to radiofrequency radiation (RFR) of the second generation mobile phones (0.9 $\mathrm{GHz}$, second generation telephony network - GSM and CDMA). The animals were divided into groups ( 90 female and 90 male in each group) and exposed at levels $0,1.5,3$ and $6 \mathrm{~W} / \mathrm{kg}$ (SAR) for 18 hours per day (10 minute exposure, 10 minute break), 7 days per week. The magnitude of the electromagnetic field was adjusted so that as the weight of the rats increased, SAR levels remained constant. The study demonstrated an increase in the number of schwannomas at a SAR level of $6 \mathrm{~W} /$ $\mathrm{kg}$ (5 in 90 rats for GSM, 6 in 90 rats for CDMA). At lower SAR levels, there was no significant increase in the number of cancers among the animals tested [17].

The second experiment of the National Toxicological Programme was carried out on mice. The animals were exposed to $1.9 \mathrm{GHz}$ electromagnetic field (second generation telephony network - GSM and CDMA). The study was carried out at SAR exposure levels - 0 (control group), 2.5, 5 and $10 \mathrm{~W} /$ $\mathrm{kg}$ (90 females and 90 males in each group until the end of the experiment). The radiation was cycled (10 minutes exposure, 10 minutes break) for 18 hours 20 minutes daily, 7 days a week from the prenatal phase for 106 (male mice) and 108 weeks (female mice). For GSM and CDMA systems, there is only inconclusive evidence of cancer in male and female individuals [12].

Further study carried out by the Ramazzini Institute (RI) in Italy is the largest animal experiment to date on the effects of the electromagnetic field produced by base stations. The experiment involved 2448 rats exposed to electromagnetic radiation from base stations. The animals were divided into 4 groups. Each group was exposed to electromagnetic field $(1.8 \mathrm{GHz}$, second generation telephony network - GSM) with different electric field strengths $(0,5,25$ and $50 \mathrm{~V} / \mathrm{m})$ 
from fetal life to natural death, 19 hours per day. The only statistically significant result of the experiment concerned male rats exposed to the highest electric field strength $-50 \mathrm{~V} / \mathrm{m}[4]$.

Exposure to electromagnetic radiation carried out during an experiment of the National Toxicological Programme (effects of mobile phones) was much higher than in the case of study carried out by the Ramazzini Institute in Italy (effects of base stations). The highest level of non-ionizing radiation for the second study was $50 \mathrm{~V} / \mathrm{m}$ and it corresponds to SAR value of about $0.1 \mathrm{~W} / \mathrm{kg}$ [17]. This is about 60 times less than the highest SAR value the animals received in an experiment conducted by the National Toxicological Programme $(6 \mathrm{~W} / \mathrm{kg})$.

These studies used a large number of animals that were irradiated throughout their lives (from fetal life to natural death). The results of the studies do not provide conclusive evidence of the carcinogenicity of radiofrequency radiation (RFR). The results of the National Toxicological Programme studies (increase in cancer cases - schwannomas in male rats) are not consistent with the results of these studies for females and mouse studies (for both males and females).

The ICNIRP (International Commission on NonIonizing Radiation Protection) has criticized the results of these studies concerning radiofrequency radiation and the associated incidence of cancer in animals. The Commission considered that the results of those studies did not provide clear conclusions on the carcinogenic effects of radiofrequency electromagnetic radiation. According to the ICNIRP, the results of the animal tests under assessment cannot serve as a basis for an evaluation of human exposure to that environmental factor. Further studies on the effects of non-ionizing radiation on living organisms are needed [8].

So far, a very large number of studies on an exposure to radiofrequency radiation (emitted by mobile phones and base stations) have been carried out. No studies have been published to confirm the carcinogenic effect of non-ionizing radiation produced by mobile phone devices. The main effect caused by the use of mobile phones is the heating of tissues (a thermal effect). For the frequencies emitted by these devices, most of the energy is absorbed by the skin. The penetration of radiation into the brain and other internal organs can be neglected. In case of negative influence of electromagnetic field on brain activity, sleep, heart rate, cognitive functions, blood pressure, no consistent evidence has been obtained so far [9].

In case of epidemiological studies and their potential long-term effects, an increased incidence of cancers (brain tumors for mobile phones) caused by an exposure to radiofrequency radiation is mainly studied. Detection of cancer shortly after an exposure is the most difficult task in analyzing the results obtained (mobile phones have been in widespread use since the early 1990s). In addition, experiments on animals do not clearly show an increase in the risk caused by non-ionizing radiofrequency radiation. Due to the lack of clear evidence and the continuous increase in the use of mobile phones (lifetime over 15 years), the World Health Organization has commissioned additional research into the relationship between an increase in cancer incidence and the use of mobile phones, especially due to the high popularity of these devices among young people (children, adolescents). These individuals should be tested because of the longer exposure period (than in adults) to electromagnetic radiation emitted by mobile phones [9].

\section{SUMMARY}

The International Agency for Research on Cancer (IARC) has classified electromagnetic radiation as a possible human carcinogen (group 2B). This factor is in the same group as many other factors in everyday life, such as talcum powder or aloe leaf extract. In contrast to ionizing radiation (X-ray or gamma radiation), electromagnetic radiation is not able to destroy the structures of molecules in the biological system, because the energies of electromagnetic radiation are too low. The only possible effect is an increase in the temperature of the tissues.

Nowadays, increasingly higher frequencies of electromagnetic radiation are used. The higher the frequency, the greater part of the radiation is absorbed by the human skin and the less it affects internal organs. However, due to the increasing development of mobile telephony (use of bands of different frequencies), increased number of studies is carried out into the possible negative (also carcinogenic) impact of electromagnetic radiation on living organisms, including humans.

Most of the studies conducted so far have not shown any correlation between the influence of electromagnetic radiation and the increased risk of cancer. At the same time, there are publications that show completely opposite results, in which the carcinogenic influence of electromagnetic radiation associated with mobile telephony is proven. Some of these studies require repetition and evaluation of the reliability and verification of the results by other scientists. Therefore, many international committees and organizations dealing with the subject of non-ionizing radiation, due to the ambiguity of published research and constantly developing technologies related to mobile telephony, commission additional studies on the impact of radiofrequency radiation on human health.

\section{Acknowledgements}

This work was financially supported by the National Institute of Public Health-National Institute of Hygiene in Warsaw, Poland, in the frame of project No BK-1, 2019. 


\section{REFERENCES}

1. Assessment of the level of electromagnetic fields in the environment in the years 2008-2017 - based on the results of measurements of the Voivodeship Inspectorates of Environmental Protection. Available www.gios.gov.pl/pl/stan-srodowiska/monitoring-polelektromagnetycznych (Accessed 04.06.2019)

2. Carlberg M., Hedendahl L., Ahonen M., Koppel T., Hardell L.: Increasing incidence of thyroid cancer in the Nordic countries with main focus on Swedish data, BMC Cancer. 2016 Jul 7;16:426, doi: 10.1186/s12885016-2429-4

3. Council Recommendation of 12 July 1999 on the limitation of exposure of the general public to electromagnetic fields (0 Hz to $300 \mathrm{GHz})(1999 / 519 /$ EC)

4. Falcioni L., Bua L., Tibaldi E., Lauriola M., De Angelis L., Gnudi F., Mandrioli D., Manservigi M., Manservisi F., Manzoli I., Menghetti I., Montella R., Panzacchi S., Sgargi D., Strollo V., Vornoli A., Belpoggi F.: Report of final results regarding brain and heart tumors in SpragueDawley rats exposed from prenatal life until natural death to mobile phone radiofrequency field representative of a 1,8 GHz GSM base station environmental emission, Environ Res. 2018 Aug;165:496-503, doi: 10.1016/j. envres.2018.01.037

5. Freudenstein F., Correia LM., Oliveira C., Sebastião D., Wiedemann PM.: Exposure knowledge and perception of wireless communication technologies, Int J Environ Res Public Health. 2015 Nov; 12(11): 14177-14191, doi: 10.3390/ijerph121114177

6. Gherardini L., Ciuti G., Tognarelli S., Cinti C.,: Searching for the perfect wave: The effect of radiofrequency electromagnetic fields on cells. Int J Mol Sci. 2014;15(4):5366-87, doi: 10.3390/ijms15045366

7. GSMA Intelligence. Available https://www. gsmaintelligence.com/ (Accessed 04.06.2019)

8. ICNIRP Note on Recent Animal Carcinogenesis Studies. Available https://www.icnirp.org/cms/upload/publications/ICNIRPnote2018.pdf (Accessed 04.06.2019)

9. Information sheet of the World Health Organization - Electromagnetic fields and public health: mobile phones. Available https://www.who.int/news-room/ fact-sheets/detail/electromagnetic-fields-and-publichealth-mobile-phones (Accessed 04.06.2019)
10. International Telecommunication Union / Worldbank. Available https://data.worldbank.org (Accessed 04.06.2019)

11. Johansen C.: Electromagnetic fields and health effects - Epidemiologic studies of cancer, disease of the central nervous system and arrhythmia-related heart disease, Scand J Work Environ Health 2004;30 Suppl 1:1-80

12. NTP Technical Report on the Toxicology and Carcinogenesis Studies in B6C3F1/N Mice Exposed to Whole-body Radio Frequency Radiation at a Frequency $(1,900 \mathrm{MHz})$ and Modulations (GSM and CDMA) Used by Cell Phones, 2018. Available https://ntp.niehs.nih. gov/ntp/about_ntp/trpanel/2018/march/tr596peerdraft. pdf (Accessed 16.07.2019)

13. Panagopoulos DJ., Johansson O., Carlo GL, Real versus Simulated Mobile Phone Exposures in Experimental Studies, Biomed Res Int. 2015;2015:607053, doi: $10.1155 / 2015 / 607053$

14. Rozporządzenie Ministra Środowiska z dnia 30 października $2003 \mathrm{r}$. w sprawie dopuszczalnych poziomów pól elektromagnetycznych w środowisku oraz sposobów sprawdzania dotrzymania tych poziomów (Dz. U. z 2003 r., Nr 192, poz. 1883) [Regulation of the Minister of the Environment of 30 October 2003 on permissible levels of electromagnetic fields in the environment and methods of verifying compliance with these levels (Journal of Laws of 2003, No. 192, item 1883)]

15. Statistics Poland, 1995-2017. Available https://stat.gov. $\mathrm{pl} /$ (Accessed 16.07.2019)

16. Ustawa $\mathrm{z}$ dnia 27 kwietnia $2001 \mathrm{r}$. Prawo ochrony środowiska (t.j. z 2018 r., poz. 799) [Act of 27 April 2001, Environmental Protection Law (Journal of Laws of 2018, item 799)]

17. Wyde M., Cesta M., Blystone C., Elmore S., Foster P., Hooth M., Kissling G., Malarkey D., Sills R., Stout M., Walker N., Witt K., Wolfe M., Bucher J.: Report of Partial Findings from the National Toxicology Program Carcinogenesis Studies of Cell Phone Radiofrequency Radiation in Hsd: Sprague Dawley ${ }^{\circledR}$ SD Rats (Whole Body Exposure). BioRxiv 055699, 2016, doi: https://doi.org/10.1101/055699

18. 5G Strategy for Poland, Ministry of Digital Affairs, January 2018. Available https://www.gov.pl/web/cyfryzacja/ strategia-5g-dla-polski(Accessed 16.07.2019)

Received: 12.06 .2019

Accepted: 17.07.2019

This article is available in Open Access model and licensed under a Creative Commons Attribution-Non Commercial 3.0.Poland License (CC-BY-NC) available at: http://creativecommons.org/licenses/by-nc/3.0/pl/deed.en 